\title{
In vitro Regeneration of Gladiolus (Gladiolus hybrida L.): Optimization of Growth Media and Assessment of Genetic Fidelity
}

\author{
Arun Kumar*, Ashwini Kumar, Vandana Sharma, Anurag Mishra, \\ Shilpy Singh and Pushpendra Kumar \\ Department of Agricultural Biotechnology, Sardar Vallabhbai Patel University of Agriculture \\ and Technology, Meerut, U.P. - 250110, India \\ *Corresponding author
}

\section{Keywords}

Gladiolus hybrida, Growth regulators, in vitro regeneration, RAPD markers

Article Info

Accepted:

20 September 2018

Available Online:

10 October 2018

\section{A B S T R A C T}

Gladiolus (Gladiolus hybrida L.) has been found as a potential cut flower cultivated world widely due to its attractive spikes and elegancy. The plant is propagated vegetatively through corms and cormels but more often its cultivation is hindered due to low multiplication rate of its corm and cormels. Gladiolus can grows through underground stems also, but it is more oftenly attacked by soil borne diseases. In vitro propagation techniques, assumes significance, especially for securing rapid multiplication of the novel cultivars using different explants sources and media. The in vitro regeneration of gladiolus cultivar White prosperity was achieved using shoot bud of cormels as an explant. The concentration and combination of plant growth regulators governed the regenerative capacity of explants. The BAP efficiently produced multiple shoots in gladiolus on B5 and MS media. The number of shoots varied from 1.3 to 3.0 shoots per explant on B5 media and 0.6 to 2.3 shoots per explant on MS media. After 30 days of incubation, the length of in vitro developed multiple shoots varied from 2.2 to $3.8 \mathrm{~cm}$ in B5 media and 1.1 to $2.9 \mathrm{~cm}$ in MS media. Also a monomorphic banding profile was obtained using Randomly Amplified Polymorphic DNA (RAPD) markers indicating that there was no genetic variation in in-vitro raised plants with respect to the mother plant when in-vitro regeneration was carried out. Hence, in vitro regeneration could be suggested for more efficient and cost effective mass propagation of Gladiolus.

\section{Introduction}

Gladiolus (Gladiolus hybrida) is a bulbous ornamental plant with great commercial importance in cut flower industry all over the world due to its magnificent and colorful spikes (Sinha et al., 2002). The major gladiolus producing countries are the United States (Florida and California), Holland, Italy, France, Poland, Bulgaria, Brazil, India,
Australia and Israel. In India, the major cut flowers grown are rose, tuberose and gladiolus (Singh et al., 2010). Amongst the cut flowers, gladiolus occupied third position in terms of both area and production. Gladiolus is being cultivated in an area of 11660 ha in the India with an estimated production of 106 crore cut flowers (Kadam et al., 2014). The major gladiolus producing states in the country are Uttar Pradesh, West Bengal, Odisha, 
Chhattisgarh, Haryana and Maharashtra. Gladiolus is also grown in states like Uttarakhand, Karnataka, Andhra Pradesh and Sikkim (Kadam et al., 2014). With the linking of India with global markets, international trade will assume considerable significance besides inducing changes in the domestic agricultural production scenario.

Gladiolus is propagated either by seeds, corm or by cormels. Although, seeds are an effective means of gladiolus propagation but seed-raised plants may not produce true-totype population (Hussain et al., 2001). In this way the conventional methods take about 8-12 years to produce sufficient number of corms of a variety for commercial cultivation (Dutta et al., 2010). The conventional propagation of gladiolus in the field faces several problems due to the slow growth and low multiplication rate of cormel and disease attacks. The involvement of Fusarium oxisporum sp. Gladioli were also known to have impacts on the growth and survival rate of the seedlings (Dantu and Bhojwani, 1995). So the introduction of new varieties or virus/fungusfree planting material of gladiolus is difficult. Therefore, novel cultivars need to be rapidly mass multiplied by using these modern regeneration technologies in order to fulfill supply gap of huge demand of market.

Therefore in vitro propagation techniques, assumes significance especially for securing rapid multiplication of the novel cultivars. Although there are several reports on in vitro propagation of gladiolus varieties, using different plant parts as explants, like shoot, bud and root, and various plant growth regulators such as 2,4-D, IAA, NAA and BAP (Misra et al., 1999; Pathania et al., 2001; Kumari et al., 2005 and Roy et al., 2006). The in vitro multiplication of gladiolus has been reported by using axillary buds (Begum et al., 1995; Boonvanno et al., 2000), shoot tip (Hussain et al., 2001), cormels (Nagaraju et al., 1995) and inflorescence axes (Ziv et al., 2000). Moreover, successful protocols for in vitro corm formation (Dantu and Bhojwani, 1995; Sen et al., 1995; Al-Juboory et al., 1995), organogenesis and somatic embryogenesis (Remotti et al., 1995; Kumar et al., 2002) have been achieved also. However, in Gladiolus there is a clear scope for further refinement through in vitro culture methodology to acquire a higher number of shoots to complement traditional nursery methods (Hussain et al., 2001). Another aspect of the current study was to check clonal fidelity between mother and in vitro regenerated propagules. Clonal multiplication is also the major concern for the horticulturist. There is a possibility that in vitro regenerated propagules exhibit somaclonal variations (Larkin et al., 1981). This variation may be caused through pre-existing genetic variation occurred in the explant and the variation induced through in vitro cultures (Skirvin et al., 1994). This variation is manifested in the form of DNA methylation, chromosome rearrangement and point mutation (Phillips et al., 1994). Long duration of in vitro culture, alterations in auxin-cytokinin concentrations, explant source and the stress created by in vitro environment all together or independently may be responsible to induce somaclonal variation (Modgil et al., 2005).

Oxidative stress is also produced by in vitro culture environment that leads to the production of free radicals within the cells and ultimately cause DNA damage (Jackson et al., 1998). In order to assess clonal fidelity, in vitro regenerated propagules need to be thoroughly checked for their clonal characters. Various PCR based molecular techniques, Random Amplified Polymorphic DNA (RAPD), Inter Simple Sequence Repeat (ISSR), Simple Sequence Repeats (SSR) and Restriction Fragment Length Polymorphism (RFLP) are nowadays more reliable for detection of clonal fidelity over morphological 
and isozymic analysis in various micropropagated plants (Carvalho et al., 2004; Martins et al., 2004). Plant tissue culture offers a potential to deliver large quantities of disease-free, true-to-type healthy stock within a short span of time (Hussain et al., 2001). The present study was undertaken for standardization of in vitro multiple shoot production protocol in gladiolus and to analyze the genetic stability of micropropagated plantlets using RAPD markers.

\section{Materials and Methods}

\section{Procurement and preparation of explant}

The healthy cormels of gladiolus cv. White prosperity were obtained from Sardar Vallabhbhai Patel University of agriculture and Technology, Meerut. The outer scale of cormels was removed and buds of cormels cut with the help of surgical blade. Then buds were washed with 3-4 drops of Twin-20 (liquid detergent) along with $0.1 \%$ bavistin followed by $70 \%$ ethanol for 4-5 minutes and $0.1 \% \mathrm{HgCl}_{2}$ for 10 minutes. After each treatment, the buds were washed 3-4 times with sterile distilled water. Buds were dried using the blotting paper before inoculated on the media.

\section{Growth media}

MS medium (Murashige and Skoog, 1962) and Gamborg (B5) medium supplemented with 0 to $4.0 \mathrm{mg} / \mathrm{l} \mathrm{BAP}$ was used for shoot regeneration. After regeneration in vitro grown shoots were transferred to the rooting medium. The media was supplemented with combination of 0 to $2.5 \mathrm{mg} / \mathrm{l} \mathrm{NAA}$ and $1.0 \mathrm{mg} / \mathrm{l}$ BAP for root induction. $30 \mathrm{~g} / \mathrm{L}$ sucrose was used as carbon source and $\mathrm{pH}$ was adjusted 5.8. Agar-agar $(0.75 \%)$ was added to solidify the media in culture tubes and jam bottles, each containing $50 \mathrm{ml}$ of the medium. In order to increase the number of shoots per culture vessel, the explants were subcultured on the same medium.

\section{DNA extraction and PCR amplification conditions}

The genomic DNA was isolated from in vitro raised plantlets by Murray and Thompson, (1980) method. Clonal fidelity of in vitro raised regenerants was tested by using 10 RAPD markers (Table 1) (Williams et al., 1990; Zietkiewicz et al., 1994). PCR amplifications were carried out in a total volume of $20 \mu \mathrm{l}$ containing $1 \mu \mathrm{l}$ of genomic DNA $(25 n g / \mu l)$ as template, $2.0 \mu 1$ of $10 \mathrm{x}$ Taq buffer, $0.6 \mu 1$ of $10 \mathrm{mM}$ dNTP, $1.0 \mu 1$ of $10 \mathrm{mM}$ primer, $0.5 \mu 1$ of $1 \mathrm{U} / \mu \mathrm{l}$ Taq polymerase and $14.9 \mu \mathrm{l}$ sterile water. PCR amplification was performed in a DNA thermal cycler (Gene Amp PCR system 9700, Applied Biosystems, CA, USA). The initial DNA denaturation at $94^{\circ} \mathrm{C}$ for 4 minute, followed by denaturation at $92^{\circ} \mathrm{C}$ for 1 minute, annealing at $37^{\circ} \mathrm{C}$ was done and 2 minute extension at $72^{\circ} \mathrm{C}$, with a final extension at $72^{\circ} \mathrm{C}$ for 7 minute. Reaction was continued for 40 cycles and the samples were then electrophoresed on $2 \%$ agarose gel.

\section{Data scoring and analysis}

The scoring of bands was done on the basis of their presence (' 1 ') or absence (' 0 '). The genetic associations were evaluated by calculating the Jaccard's similarity coefficient for pair-wise comparisons based on the proportion of shared bands produced by the primers. The similarity matrix was subjected to the cluster analysis of unweighted pair group method with arithmetic averages (UPGMA) and a dendrogram was generated by using NTSYS-pc version 2.1 software (Rohlf, 2000). Data were subjected to analysis of variance for a factorial experiment. Critical differences (CD) were calculated to determine the statistical significance of different 
treatment means. Consistent, well-resolved fragments in the size range of $100 \mathrm{bp}$ to $3000 \mathrm{bp}$ were manually scored.

\section{Results and Discussion}

In vitro propagation technique by using shoot buds as explants from gladiolus cormel was carried out on different media in order to develop a cost-effective method for clonal production of gladiolus. The present study on "In vitro regeneration of gladiolus (Gladiolus hybrida): optimization of growth media and assessment of genetic fidelity" was carried out on cultivar White prosperity.

\section{Shoot organogenesis}

Multiplication is usually achieved through excessive shoot proliferation and there after transfer of in vitro developed shoots to rooting media. The organogenesis of shoots can be obtained in two different ways either through direct development of shoots from different explant sources, such as cormel's shoot tip cultures or by shoot development through callus phase. Various stages/sizes of any explant might have different regenerative capacity and this regenerative capacity is much dependent upon the concentration and combination of plant growth regulators (Memon et al., 2013). In present study BAP produced efficient number of shoots in gladiolus and it was found as a potent cytokinin. The number of regenerated shoot found to be varying with the mean 1.3 to 3.0 and 0.6 to 2.3 shoot per explant in B5 and MS media respectively. Induction of shoot bud was observed within 7-8 days in B5 media 1011 days in MS media (Fig. 1). Maximum length and numbers of shoots were found in both medium when it was supplemented with $1.0 \mathrm{mg} / \mathrm{l}$ of BAP, while minimum at $0.5 \mathrm{mg} / \mathrm{l}$ of BAP. The shoot length and number of shoots were maximum in B5 media and MS media with the mean value $3.8000 \mathrm{~d}, 3.0333 \mathrm{~d}$ and
$2.9000 \mathrm{e}, 2.3000 \mathrm{f}$ respectively, while minimum were recorded at $0.5 \mathrm{mg} / \mathrm{l} \mathrm{BAP}$ with the mean value $0.500,0.2666$ and $1.1033,0.6000 \mathrm{~b}$ respectively (Table 1). The low concentration of BAP (1 mg/l) produces more number of shoots (upto 16 per culture vessel) from cormels (Aftab et al., 2008). Grewal et al., (1995) obtained single shoot per explant on MS medium supplemented with $1 \mathrm{mg} / \mathrm{l}$ BAP in cultivars viz. Mayur, Sylvia, Spic and Span, whereas 14-20 shoot primordial obtained within 4 weeks when cultured on MS medium with $5 \mathrm{mg} / \mathrm{l}$ BAP. Higher dose requirement of BAP was recognized as to be genotype dependent (Hussain et al., 2001).

The differences in in-vitro response might be due to cormel size or varietal differences as the effect of concentration and combination of PGR varied with variety and explant size. Top section of cormel showed better potential for efficient shoot regeneration with BAP supplementation $(4 \mathrm{mg} / \mathrm{l})$. Better shoot induction (upto 89\%) was observed with top slice of cormel (dia. 1.0 to $1.5 \mathrm{~cm}$ ) in response to MS medium containing $4 \mathrm{mg} / \mathrm{l} \mathrm{KIN}$ rather than BAP (Babu and Chawla, 2000).

One of the possible reasons for successful regeneration might be the presence of growing point (meristematic tissues) in the cormel or the direct contact of physiological base of the cormel top section with the media which further increased the absorption area for nutrient uptake. Regarding bottom section of cormels, most of the cultures exhibited mortality where the physiological base of the bottom section was on the nutrient medium and the cut surface on upper side. The large cut surface might be the reason of death of explants due to oxidative stress as there might be a possibility of free radical generation that led to activation of peroxidases, catalase and SOD enzymes (Olmos et al., 1994). Transverse slices of cormel showed no regeneration (Emek and Erdag, 2007). 
Table.1 Shoot induction in B5 and MS medium

\begin{tabular}{|c|c|c|c|c|c|}
\hline \multirow[t]{2}{*}{ S. No. } & \multicolumn{3}{|c|}{ B5 medium } & \multicolumn{2}{|c|}{ MS medium } \\
\hline & $\begin{array}{c}\text { Concentration of } \\
\text { BAP (mg/l) }\end{array}$ & $\begin{array}{l}\text { No. of shoots } \\
\text { per explant }\end{array}$ & $\begin{array}{l}\text { Shoot length } \\
\text { per explant } \\
(\mathrm{cm})\end{array}$ & $\begin{array}{l}\text { No. of shoots } \\
\text { per explant }\end{array}$ & $\begin{array}{c}\text { Shoot length } \\
\text { per explant } \\
(\mathrm{cm})\end{array}$ \\
\hline 1 & - & $0.26 \pm 0.08 \mathrm{a}$ & $0.50 \pm 0.05 \mathrm{a}$ & - & - \\
\hline 2 & 0.5 & $1.30 \pm 0.11 b$ & $2.23 \pm 0.04 b$ & $0.6 \pm 0.05 \mathrm{~b}$ & $1.10 \pm 0.12 b$ \\
\hline 3 & 1.0 & $3.03 \pm 0.27 \mathrm{~d}$ & $3.80 \pm 0.04 d$ & $2.30 \pm 0.11 \mathrm{f}$ & $2.90 \pm 0.11 \mathrm{e}$ \\
\hline 4 & 1.5 & $2.0 \pm 0.13 c$ & $2.50 \pm 0.57 c$ & $1.23 \pm 0.12 c$ & $2.10 \pm 0.05 \mathrm{~cd}$ \\
\hline 5 & 2.0 & $2.13 \pm 0.08 \mathrm{c}$ & $2.30 \pm 0.57 \mathrm{e}$ & $1.40 \pm 0.05$ & $2.23 \pm 0.0333$ \\
\hline 6 & 3.0 & $1.50 \pm 0.11 b$ & $2.60 \pm 0.57 c$ & $1.70 \pm 0.11 \mathrm{e}$ & $2.30 \pm 0.11 \mathrm{~d}$ \\
\hline 7 & 4.0 & $2.23 \pm 0.12 \mathrm{c}$ & $3.10 \pm 0.11 \mathrm{~d}$ & $1.60 \pm 0.05 \mathrm{de}$ & $2.0 \pm 0.05 c$ \\
\hline & $\begin{array}{l}\text { CD- } \\
\text { CV- }\end{array}$ & $\begin{array}{c}0.44 \\
14.14\end{array}$ & $\begin{array}{l}0.20 \\
4.65\end{array}$ & $\begin{array}{c}0.28 \\
12.68\end{array}$ & $\begin{array}{l}0.26 \\
8.15\end{array}$ \\
\hline
\end{tabular}

*Each treatment consists of 3 replicates. *Means followed by the same letters $(a, b, c)$ are not significantly different $(p<0.05)$ using Duncan New Multiple Range Test (DMRT’s test).

Table.2 Root induction in B5 and MS medium

\begin{tabular}{|c|c|c|c|c|c|}
\hline \multirow[t]{2}{*}{ S. No. } & \multirow{2}{*}{$\begin{array}{l}\text { Concentration } \\
\text { of NAA (mg/l) } \\
\text { along with } \\
\text { BAP }(1 \mathrm{mg} / \mathrm{l})\end{array}$} & \multicolumn{2}{|c|}{ B5 Medium } & \multicolumn{2}{|c|}{ MS Medium } \\
\hline & & Root Length & $\begin{array}{l}\text { Number of } \\
\text { roots }\end{array}$ & Root Length & $\begin{array}{l}\text { Number of } \\
\text { roots }\end{array}$ \\
\hline 1 & 0.0 & $0.3 \pm 0.12 \mathrm{a}$ & $2.0 \pm 0.54 \mathrm{a}$ & $0 \pm 0.0 \mathrm{a}$ & $0 \pm 0.0 \mathrm{a}$ \\
\hline 2 & 0.1 & $0.8 \pm 0.11 b$ & $3.0 \pm 0.54 \mathrm{a}$ & $0 \pm 0.0 \mathrm{a}$ & $0 \pm 0.0 \mathrm{a}$ \\
\hline 3 & 0.5 & $1.4 \pm 0.07 \mathrm{c}$ & $5.0 \pm 0.31 \mathrm{~b}$ & $0.36 \pm 0.16 b$ & $2.0 \pm 0.44 \mathrm{~b}$ \\
\hline 4 & 1.0 & $2.2 \pm 0.12 \mathrm{~d}$ & $5.4 \pm 0.40 \mathrm{~b}$ & $0.76 \pm 0.09 c$ & $2.0 \pm 0.54 \mathrm{~b}$ \\
\hline 5 & 1.5 & $3.2 \pm 0.10 \mathrm{f}$ & $6.0 \pm 0.44 \mathrm{~b}$ & $0.96 \pm 0.09 \mathrm{~cd}$ & $3.0 \pm 0.54 b c$ \\
\hline 6 & 2.0 & $2.8 \pm 0.07 \mathrm{e}$ & $5.0 \pm 0.44 \mathrm{~b}$ & $1.40 \pm 0.09 \mathrm{e}$ & $4.0 \pm 0.44 \mathrm{e}$ \\
\hline 7 & 2.5 & $2.4 \pm 0.08 \mathrm{~d}$ & $3.0 \pm 0.44 \mathrm{a}$ & $1.16 \pm 0.09 \mathrm{~d}$ & $3.2 \pm 0.37 b c$ \\
\hline & $\begin{array}{l}\text { CD- } \\
\text { CV- }\end{array}$ & $\begin{array}{c}0.27 \\
11.21\end{array}$ & $\begin{array}{c}1.33 \\
24.31\end{array}$ & $\begin{array}{c}0.27 \\
30.83\end{array}$ & $\begin{array}{c}1.17 \\
44.48\end{array}$ \\
\hline
\end{tabular}

*Each treatment consists of 3 replicates. *Means followed by the same letters $(\mathrm{a}, \mathrm{b}, \mathrm{c})$ are not significantly different $(p<0.05)$ using Duncan New Multiple Range Test (DMRT's test). 
Fig.1 A. shoot induction on B5 media, B. shoot induction on MS media, C and D. root induction, E. subcultured growth of shoot on B5 media and F. subcultured growth on MS media
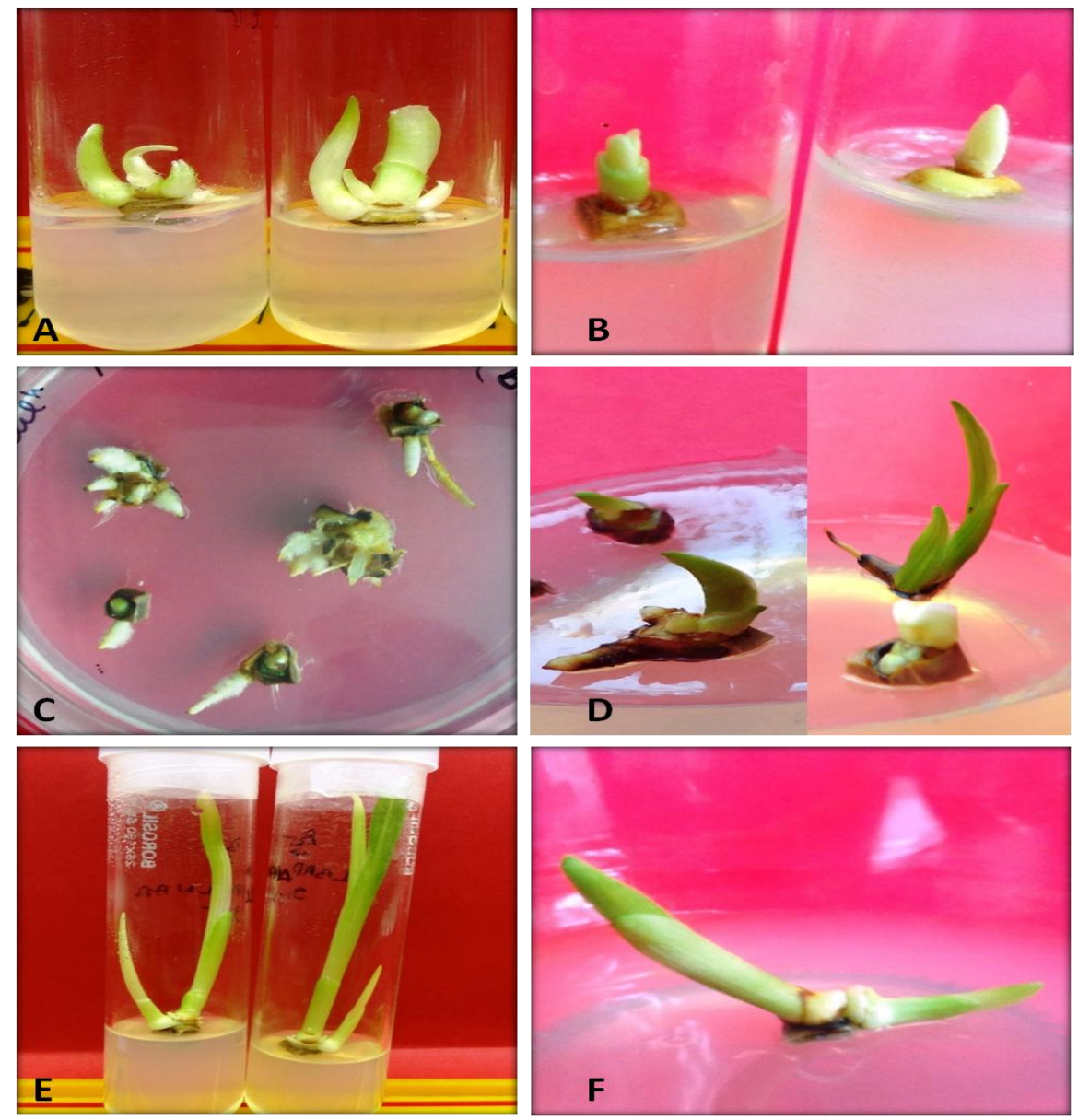

Fig.2 RAPD primers, (A) OPA 09, (B) OPA 01 and (C) OPA 10 profiling pattern

A

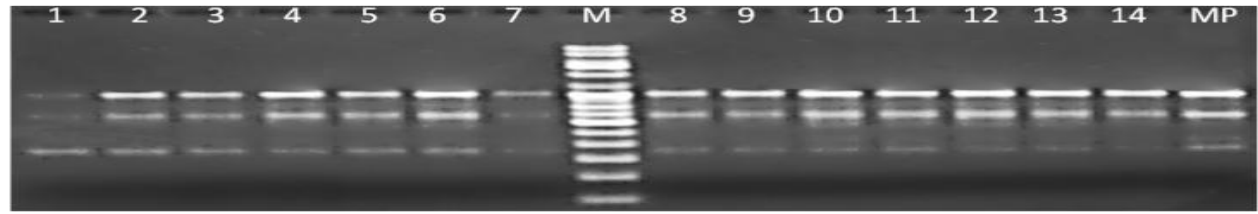

B
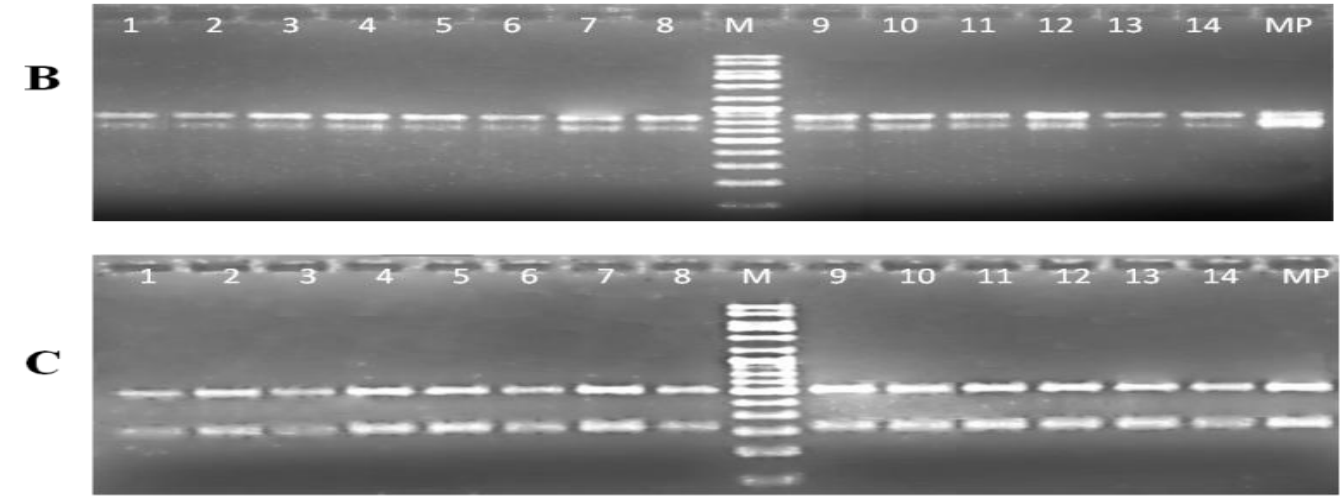


\section{Root development}

In vitro grown multiple shoots were subculture for root induction on both B5 and MS medium enriched with various concentrations of NAA along with BAP. The culture was incubated at $25^{\circ} \mathrm{C} \pm 22^{\circ} \mathrm{C}$ with $16 / 8$ $\mathrm{hr}$ light/dark regime under fluorescent light. Data was observed after four weeks of subculture. The root regeneration has been found to be varying with the mean value $2 \mathrm{a}$ to $6 \mathrm{~b}$ and $0 \mathrm{a}$ to $4 \mathrm{c}$ root per explant in B5 and MS media respectively. Induction of roots from plantlets was observed within 6-9 days in B5 media 7-11 days in MS media (Figure 1). Maximum length and numbers of roots were found in B5 media when it was supplemented with $1.0 \mathrm{mg} / \mathrm{l}$ of BAP and $1.5 \mathrm{mg} / \mathrm{l}$ NAA, whereas maximum length and numbers of roots were found in MS media when it was supplemented with $1.0 \mathrm{mg} / \mathrm{l}$ of BAP and 2 $\mathrm{mg} / \mathrm{l}$ NAA. While minimum length and numbers of roots were found at $1.0 \mathrm{mg} / \mathrm{l} \mathrm{BAP}$ $0.1 \mathrm{mg} / \mathrm{L}$ NAA in both media. The root length and number of roots were maximum in B5 media as compared to MS media (Table 2). Highest number of roots (upto 24) were also recorded in cv. "Peach blossom" on MS medium containing $1 \mathrm{mg} / \mathrm{l}$ NAA (Priyakumari and Sheela, 2005). It has also been previously reported that very poor response was obtained in case of root initiation on MS medium containing IBA or NAA while sucrose concentration show positive effect on the rooting response and quality of roots in different cultivars (Kumar et al., 1999).

\section{Genetic fidelity}

Plants regenerated from adventitious buds around axillary buds or from other well developed meristematic tissue showed the lowest tendency of genetic variation (Rout et al., 1998; Joshi and Dhawan, 2007), whereas plants derived from callus as compared to those raised from embryogenic tissues showed more variations (Al-Zahim et al., 1999; Yang et al., 1999). Previous reports also suggested that even plants derived from organized meristems are not always genetically true to type in many crops (Devarumath et al., 2002). Hence, it becomes imperative to regularly check the genetic purity of the micro-propagated plants in order to produce clonally uniform progeny while using different techniques of micropropagation. The presence or absence of variations during in vitro propagation depends upon the source of explants and method of regeneration (Goto et al., 1998). The sub- and supra-optimal levels of plant growth substances, especially synthetic ones, have also been associated with somaclonal variation (Martin and Pachathundkandi, 2006). Even at optimal levels, long-term multiplication often may lead to somaclonal or epigenetic variations in micro-propagated plants thus questioning the very fidelity of their clonal nature. During this study total 35 distinct bands produced in fourteen in vitro regenerated clones and one mother plant. A total number of 525 bands were generated by all primers showed monomorphic banding pattern. The number of scorable bands for each primer varied from 2 (OPA10 and OPA $01)$ to 5 (OPA 15) with an average of 3.5 bands per primer. Primer OPA 01 produced two bands with the length $350 \mathrm{bp}$ and $450 \mathrm{bp}$ (Figure 2), primer OPA 10 also produced two bands, $160 \mathrm{bp}$ and 300bp long (photo plate 2.C). Three bands were produced by four primers i.e. OPA 04, OPA 07, OPA 09 and OPA 16. The primer OPP 05 produced four bands vary from $170 \mathrm{bp}$ to $300 \mathrm{bp}$. Three primers OPA 15, OPA 17 and OPA 19 produced the five distinct bands with a length of 80 to $340 \mathrm{bp}, 125$ to $520 \mathrm{bp}$ and180bp to $580 \mathrm{bp}$ respectively in each clone along with mother (Fig. 2). Thus in vitro regenerated plants shows genetic similarity with their mother plant. Clones derived from cormel's shoot tip explants were however true to their 
type, one leaf-derived clone showed genetic variation (Bhatia et al., 2010).

The findings of Potter and Jones, (1991) state that somaclonal variations are associated with regeneration from undifferentiated tissues and plants regenerated from existing meristems are genetically stable. These findings support the fact that meristem-based micropropagation system is much more stable genetically than those in which regeneration occur via callus phase.

\section{Acknowledgement}

We are thankful to the Department of Agriculture Biotechnology, SVPUAT, Meerut for providing necessary facilities.

\section{References}

Aftab F., Alam M. and Afrasiab H. (2008). In-vitro shoot multiplication and callus induction in Gladiolus hybridus Hort. Pak. J. Bot., 40 (2): 517-522.

Al-Juboory K.H., Shibli R.A. and Skiryn R. (1995). Organogenesis and cormel production from callus culture of gladiolus cv. Balady. Mu'tah. J. Res. Stud., 12: 143-160.

Al-Zahim M. A., Ford-Lloyd B.V., Newbury H.J. (1999). Detection of somaclonal variation in garlic (Allium sativum L.) using RAPD and cytological analysis. Plant Cell Rep., 18: 473-477.

Babu P., and Chawla H.S. (2000). In vitro regeneration of Agrobacterium mediated transformation in gladiolus. $J$. Hort. Sci. Biotechnol., 75: 400-404.

Begum S. and Haddiuzaman S. (1995). In vitro rapid shoot proliferation and corm development in Glaiolus grandiflorus cv. Red brand. Plant Tissue Cult., 5: 7 12.

Bhatia R., Singh K.P., Sharma T.R., Jhang T. (2010). Evaluation of the genetic fidelity of in-vitro propagated gerbera (Gerbera jamesonii Bolus) using DNAbased markers. Plant Cell Tissue Organ Cult., 36: 311-317.

Boonvanno K. and Kanchanapoom K. (2000). In-vitro propagation of gladiolus. Suranaree J. Sci. Technol. 7: 25-29.

Carvalho L.C., Goulao L., Oliveira C., Goncalves J.C. and Amancio S. (2004). RAPD assessment for identification of clonal identity and genetic stability of in-vitro propagated Chestnut hybrids. Plant Cell Tiss. Org. Cult., 77: 23-27.

Dantu P.K and Bhojwani S.S (1995). In vitro corm formation and field evalution of corm derived plants of gladiolus. Sci. Hort., 61: 115-129.

Devarumath R.M., Nandy S., Rani V., Marimuthu S., Muraleedharan N., Raina S.N. (2002). RAPD, ISSR and RFLP fingerprints as useful markers to evaluate genetic integrity of micropropagated plants of three diploid and triploid elite tea clones representing Camellia sinensis (China type) and C. assamica ssp. Assamica (Assam-India type). Plant Cell Rep., 21: 166-173.

Dutta K., Kharb P., Rana G. S. and Sehrawat S. K. (2010). Studies on in vitro multiplication of gladiolus cultivars. Haryana J. Hortic. Sci., 39(1\&2): 149152.

Emek Y. and Erdag B. (2007). In vitro propagation of Gladiolus anatolicus. Pak. J. Bot., 39(1): 23-30.

Goto S., Thakur R.C., Ishii K. (1998). Determination of genetic stability in long-term micro-propagated shoots of Pinus thunbergii Parl. using RAPD markers. Plant Cell Rep, 18: 193-197.

Grewal, M.S., Arora, J.S. and Gosal, S.S. (1995). Micropropagation of gladiolus through in vitro cormel production. Plant Tissue. Cult. 5:27-33. 
Hussain I., Muhammad A., Rashid H. and Quraishi A. (2001). In vitro multiplication of gladiolus (Gladiolus crassifolius). Plant Tissue Cult. 11: 121-126.

Jackson A.L., Ru C. and Lawrence L.A. (1998). Induction of microsatellite instability by oxidative DNA damage. Proc. Nat. Acad. Sci., 95: 12468-12473.

Joshi P. and Dhawan V. (2007). Assesment of genetic fidelity of micro-propagated Swertia chirayita plantlets by ISSR marker assay. Biologia Plantarum, 51(1): 22-26.

Kadam J.J, Agale R.C, Rite S.C, Pandav S.M (2014). Exploration of fungicides and phyto extract against Fusarium oxysporum sp. Gladioli causing corm rot of gladiolus. Discovery Agriculture, 2(9): 61-64.

Kumar A., Palni L.M.S., Sood A., Sharma M., Palni U.T. and Gupta A.K. (2002). Heat shock induced somatic embryogenesis in callus cultures of gladiolus in the presence of high sucrose. Journal of Hort. Sci. and Biotech., 77(1):73-78.

Kumar A., Sood A., L.M.S. Palni and Gupta A.K.A. (1999). In vitro propagation of gladiolus hybridus hort.: Synergistic effect of heat shock and sucrose on morphogenesis. Plant Cell Tiss. Org. Cult., 57: 105-112.

Larkin P.J. and Scowcroft W.R. (1981). Somaclonal variation-a novel source of variability from cell cultures for plant improvement. Theor. and Appl. Genetics, 60: 197-214.

Martins K.P., Pachathundkandi S.K., Zhang C.L. and Slater A. (2006). RAPD analysis of a variant of banana (Musa sp.) cv. Grande Naine and its propagation via shoot culture. In Vitro Cell Dev. Biol., 42: 188-192.

Martins M., Sarmento D. and Oleveira M.M. (2004). Genetic stability of micropropagted almond plantlets as assessed by RAPD and ISSR markers. Plant Cell Rep., 23: 492-496.

Memon N., Muhammad Q., Muhammad J. J., Aijaz A. K., Zahoor $\mathrm{H}$ and Ahmad I. (2013). Comparison of various explants on the basis of efficient shoot regeneration in gladiolus. Pak. J. Bot., 45(3): 877-885, 2013.

Misra S. and Singh R. (1999). In vitro propagation of gladiolus cv. 'American Beauty’. J. Ornam. Hort., 2: 67-70.

Modgil M., Mahajan K., Chakrabarti S.K., Sharma D.R. and Sobti R.C. (2005). Molecular analysis of genetic stability in micro-propagated apple rootstock MM106.Sci. Hort., 104: 151-160.

Murashige T. and Skoog F. (1962). A revised medium for rapid growth and bioassays with tobacco tissue cultures. Physiol. Plant., 15:473-497.

Murray M.G., Thompson W.F (1980). Rapid isolation of high molecular weight plant DNA. Nuc. Acids Res., 8: 4321-4325.

Nagaraju V. and Parthasarthy V.A. (1995). Effect of growth regulators on in vitro shoots of Gladiolus hybridus. Folia Hort, 7: 93-100.

Olmos E., Hernandez J.A., Sevilla F. and Hellín E. (1994). Induction of several antioxidant enzymes in the selection of a salt tolerant cell line of Pisum sativum. Journal of Plant Physiology, 114: 594-598.

Pathania N.S., Misra R.L. and Raghava S.P.S. (2001). Precocious shoot proliferation and microcorm production in gladiolus through tissue culture. Journal of Ornamental Horticulture, 4: 69-73.

Phillips R.L., Kaeppler S.M. and Olhoft O. (1994). Genetic instability of plant tissue cultures: Breadkdown of normal controls. Proc. Nat. Acad. Sci., 91: 5222-5226.

Potter, R., Jones and M.G.K., (1991). An assessment of genetic stability of potato 
in vitro by molecular and phenotypic analysis. Plant Sci., 76: 239-248.

Priyakumari and Sheela V.L. (2005). Micropropagation of gladiolus $\mathrm{cv}$. 'Peach Blossom' through enhanced release of axillary buds. J. Trop. Agric, 43: 47-50.

Remotti P.C. and Loffler H.J.M. (1995). Callus induction and plant regeneration from gladiolus. Plant Cell, Tissue and Organ Culture, 42: 171-178.

Rohlf FJ (2000). NTSYS-pc: numerical taxonomy and multivariate analysis system, version 2.1. Exeter Software, Setauket, New York

Rout G.R., Das P., Goel S. and Raina S.N. (1998). Determination of genetic stability of micro-propagated plants of ginger using Random Amplified Polymorphic DNA (RAPD) markers. Botanical Bulletin of Academia Sinica, 39: 23-27.

Roy S.K., Gangopadhyay G., Bandyopadhyay T., Modak B.K., Datta S. and Mukherjee K.K. (2006). Enhancement of in vitro micro corm production in gladiolus using alternative matrix. African J. Biotechnol., 5: 1204-1209.

Sen, J. and Sen S. (1995). Two step bud culture technique for a high regeneration of gladiolus corm. Sci. Hort., 64: 133-138.
Sinha P. and Roy S.K. (2002). Plant regeneration through in vitro cormel formation from callus culture of Gladiolus primulinus Baker. Plant Tiss. Cult., 12: 139-145.

Skirvin R.M., Mcpheeters K.D. and Norton M. (1994). Sources and frequency of somaclonal variation. Hort. Sci., 29: 1232-1237.

Williams J.G.K., Kubelik A.R., Livak K.J., Rafalski J.A. and Tingey S.V. (1990). DNA polymorphisms amplified by arbitrary primers are useful as genetic markers. Nucleic Acids Res., 18: 65316535.

Yang H., Tabei Y., Kamada H., Kayamo T. and Takaiwa F. (1999). Detection of somaclonal variation in cultured rice cells using digoxygenin-based random amplified polymorphic DNA. Plant Cell Rep., 18: 520-526.

Zeitkiewicz E, Rafalski A, Labuda D (1994). Genome finger printing by simple sequence repeat (SSR)-anchored PCR amplification. Genomics 20:176-183.

Ziv M. and Lilien-Kipnis H. (2000). Bud regeneration from inflorescence explants for rapid propagation of geophytes in vitro. Plant Cell Rep., 19: 845-850.

\section{How to cite this article:}

Arun Kumar, Ashwini Kumar, Vandana Sharma, Anurag Mishra, Shilpy Singh and Pushpendra Kumar. 2018. In vitro Regeneration of Gladiolus (Gladiolus hybrida L.): Optimization of Growth Media and Assessment of Genetic Fidelity. Int.J.Curr.Microbiol.App.Sci. 7(10): 29002909. doi: https://doi.org/10.20546/ijcmas.2018.710.337 